\title{
ANALISIS PERAN PEMUDA DALAM PENGEMBANGAN WISATA HALAL DI KOTA SABANG
}

\author{
Bachtiar Ahmad Fani Rangkuti*, Suwardi Lubis, Agus Purwoko \\ Universitas Sumatera Utara, Medan, Indonesia \\ bachtiarahmadfanirangkuti@uinsu.ac.id
}

\begin{abstract}
The Aceh Provincial Government develops Sabang as a tourism industry in order to make it a new destination alternative in Aceh, and youngsters are regarded as the appropriate persons to manage halal tourism. This condition needs profound analysis. The objective of this research wa to analyze 1) the influence of social factors simultaneously on the role of youth in developing halal tourism in Sabang, and 2) the influence of social factors partially on the role of youth in developing halal tourism in Sabang. The research used descriptive quantitative approach. The result of the the research showed that 1) all questions were considered valid and reliable, 2) all statements were considered valid and reliable, and 3) social factors simultaneously had the positive and significant influence on the role of youth in developing halal tourism in Sabang. Partially, the variables of age $\left(X_{1}\right)$, gender $\left(X_{2}\right)$, and formal education $\left(X_{3}\right)$, had positive and significant influence while the vaiables of informal education $\left(X_{4}\right)$ and occupation $\left(X_{5}\right)$ had positive but insignificant influence.
\end{abstract}

Keywords: Role of Youth, Halal Tourism, Regional Development

\begin{abstract}
Abstrak
Pemerintah Provinsi Aceh mengembangkan Kota Sabang sebagai industri pariwisata bertujuan menjadikan alternatif destinasi baru yang ada di Provinsi Aceh. Sumber daya manusia yang paling tepat dalam mengelola aspek wisata khususnya wisata halal adalah para pemuda. Hadirnya para pemuda dalam pengembangan wisata halal memerlukan analisis yang lebih mendalam. Penelitian ini bertujuan untuk: (1) Menganalisis pengaruh faktor-faktor sosial secara simultan terhadap peran pemuda dalam pengembangan wisata halal di Kota Sabang, (2) Menganalisis pengaruh faktor-faktor sosial secara parsial terhadap peran pemuda dalam pengembangan wisata halal di Kota Sabang. Penelitian analisis peran pemuda dalam pengembangan wisata halal di Kota Sabang ini menggunakan penelitian deskriptif dengan pendekatan kuantitatif. Hasil penelitian ini menunjukkan bahwa: (1) Seluruh pertanyaan dinyatakan valid dan dinyatakan reliable. (2) Seluruh pernyataan dinyatakan valid dan dinyatakan reliable. (3) foktor-faktor sosial secara simultan memiliki pengaruh terhadap peran pemuda dalam pengembangan wisata halal di Kota Sabang secara positif dan signifikan. Variabel Umur $\left(\mathrm{X}_{1}\right)$ secara parsial berpengaruh positif signifikan, Variabel Jenis Kelamin (gender) $\left(\mathrm{X}_{2}\right)$ secara parsial berpengaruh positif signifikan, Variabel Pendidikan Formal $\left(\mathrm{X}_{3}\right)$ secara parsial berpengaruh positif signifikan, Variabel Pendidikan Informal $\left(\mathrm{X}_{4}\right)$ secara parsial berpengaruh positif tidak signifikan dan Variabel Pekerjaan $\left(\mathrm{X}_{5}\right)$ secara parsial berpengaruh positif tidak signifikan.
\end{abstract}

Kata kunci: Peran Pemuda, Wisata Halal, Pengembangan Wilayah 


\section{PENDAHULUAN}

Pariwisata berasal dari kalimat wisata yang secara bahasa berarti perjalanan (traveling), sedangkan wisatawan secara bahasa berarti seseorang ataupun sekelompok orang yang sedang berkunjung kesuatu wilayah (travelers). Gamal mendefinisikan kalimat pariwisata sebagai suatu perubahan tempat tinggal sementara yang dilakukan oleh seseorang ataupun kelompok karena ingin mendapatkan kenikmatan dari perjalanan, bukan sedang mendapatkan atau mengharapkan imbalan dari sebuah pekerjaan (Gamal, 2004).

Kata halal pada dasarnya berasal dari kosa kata Arab yang berarti sesuatu yang dibolehkan atau diizinkan berdasarkan ketentuan aturan Islam, hal ini terkait dengan kualitas kepercayaan penganut (Jafari dan Scott, 2014). Masyarakat muslim secara umum saat ini menyadari bahwasannya kata halal tidak hanya terkait kepada hewan, pemotongan hewan dan penyajian makanan saja, akan tetapi kata halal juga terkait terhadap keadanan sosial. Terkait dengan bisnis kata halal mengacu pada cara atau metode yang dilazimkan dalam Islam (Rezai, 2008).

Masyarakat beragama Islam awalnya memahami pariwisata halal hanya untuk memenuhi kebutuhan spiritualnya saja, berziarah termasuk kedalam bagian pariwisata yang dimaksud (Jaelani, 2016). Saat ini konteks pariwisata halal mulai bergeser seiring dengan bidang pariwisata yang sudah menjadi bagian dari industri atau kegiatan bisnis, yang bertujuan untuk meningkatkan pendapatan masyarakat lokal. Hadirnya industri pada pariwisata halal pada akhirnya merubah konsep pariwisata semula hanya mencakup tentang situs ziarah dan keagamaan akan tetapi juga mencakup ketersediaan fasilitas pendukung, seperti tempat makan, tempat penginapan yang menyediakan makanan halal dan juga tempat sholat.

Masyarakat non-muslim dalam memahami kata halal hanya sampai kepada produk berkualitas saja. Hal ini dikarenakan narasi yang berkembang mengenai kata halal hanya terputus terhadap sebuah merek dagang. Padahal jika ditelusuri kata halal merupakan sebuah landasan filosofi yang jelas mengarah terhadap pemasaran yang lebih mengembangkan produk. Jika diperluas lagi akan masuk kedalam aspek disiplin ilmu yang membahas tentang aspek sosial (Wilson dan Liu, 2011). Lebih jauh dalam pelaksanaan kehidupan sehari-hari, para muslim memahami akan beberapa posisi antara aktivitas yang makruh (lebih baik dihindarkan) dan subhat (diluar kebiasaan cenderung dilarang).

Hadirnya Indonesia dalam industri pariwisata halal selain dilatar belakangi oleh mayoritas penduduknya yang beragama muslim, juga dilimpahkan sumber daya alam yang 
begitu beragam, mulai dari daratan yang memiliki ragam hayati dan lautan yang lebih luas dari daratan menjadikan Indonesia terkenal dengan istilah sea, sun, sand and mainland, (Setiawan, 2015). Letak geografis yang terpisah ini menjadikan wilayah-wilayah di daerah potensi wisata mulai mengelola dan mengembangkan diri untuk menjadikan daerahnya sebagai kawasan pariwisata. Salah satu wilayah paling Barat Indonesia bernama Provinsi Aceh merupakan salah satu dari beberapa daerah potensi yang dapat diolah menjadi sumber pemasukan khususnya bagi pendapatan daerah dan nasional pada umunya.

Provinsi Aceh dengan Undang-Undang Nomor 44 Tahun 1999 Tentang Penyelenggaraan Keistimewaan Provinsi Daerah Istimewa Aceh. Maka dalam kaitannya dengan pengelolaan dan pengembangan wisata, Pemerintah Provinsi Aceh mengeluarkan aturan khusus yang disebut Qanun Aceh Nomor 8 Tahun 2013 Tentang Kepariwisataan, aturan yang dikeluarkan tersebut tentunya berasaskan nilai-nilai ke-Islaman sesuai dengan pengelolaan dan pengembangan wisata halal. Dan beberapa tahun silam telah dikeluarkan juga Qanun Aceh Nomor 8 Tahun 2016 Tentang Sistem Jaminan Produk Halal.

Provinsi yang berjuluk serambi mekah ini dalam mengembangkan wisata halal cukup terlihat serius, hal ini dapat dinilai dari keberhasilannya meraih dua penghargaan pada tahun 2016 lalu dari World Halal Tourism. Sedangkan di Tahun 2019 lalu Kota Sabang juga mendapatkan penghargaan sebagai destinasi wisata terunik (API). Kota Sabang merupakan wilayah awal batas atau wilayah paling ujung dari Pulau Sumatera, Pulau Sabang juga sering disebut sebagai Nol Kilometer (Zalikha 2015). Sebagai pulau yang berada diujung, tak bisa dipungkiri Pulau Sabang dalam melakukan pengembangan wisata halal memiliki keterbatasan dalam menyediakan produk, fasilitas, infrastruktur dan pelayanan terhadap para wisatawan, hal ini dikarenakan stakeholder terkait memiliki keterbatasan sumber daya manusia yang berperan dalam proses mengembangkan wisata halal.

Sumber daya manusia sama-sama kita ketahui merupakan salah satu aspek yang berhubungan langsung dengan pengembangan pariwisata, sumber daya manusia yang dimaksud adalah secara individu atau kelompok-kelompok, mereka dikombinasikan untuk melaksanakan, melayani atau menyediakan layanan kebutuhan perjalanan wisata. Hal ini tertulis dalam PERPU Nomor 50 tahun 2011 Tentang Rencana Induk Pembangunan Kepariwisataan Nasional Tahun 2010-2025. Hadirnya para pemuda dalam pengembangan wisata halal memerlukan analisis yang lebih mendalam, agar keinginan dalam pengembangan wisata halal tercapai. Hal ini dikarenakan para pemuda memiliki faktor-faktor sosial yang beragam, 


\section{JURNAL PEMBERDAYAAN MASYARAKAT 189 \\ Volume 9 No. 2 Tahun 2021 ISSN: 2355-8679}

Berdasarkan hal tersebut, penulis merasa perlu untuk melakukan penelitian terkait seberapa berpengaruh faktor-faktor sosial terhadap peran pemuda di Kota Sabang dalam upaya pengembangan industri wisata halal. Sehingga peran pemuda bisa dianalisis sampai sejauh mana kontribusinya dalam perubahan yang diwujudkan dengan pembangunan aspek sumber daya ekonomi

\section{METODE PENELITIAN}

Penelitian ini menggunakan penelitian deskriptif melalui pendekatan kuantitatif. (Fred, 2019) deskriptif bertujuan untuk mendeskripsikan hal (being) dan keperiadaan (existence) satu fenomena sebagaimana adanya. Populasi dalam penelitian ini adalah para pemuda dan pemudi yang berdasarkan dengan Undang Undang Nomor 40 Tahun 2009 Tentang Kepemudaan yang berdomisili di Kota Sabang. Berikut dapat dilihat pada tabel 3.1 jumlah penduduk berdasarkan kelompok umur dan jenis kelamin di Kota Sabang.

Tabel 1. Jumlah Penduduk Berdasarkan Kelompok Umur dan Jenis Kelamin

\begin{tabular}{|c|c|c|c|}
\hline No & USIA & N & PERSENTASE \\
\hline 1 & $15-19$ & 2.169 & $26.9 \%$ \\
\hline 2 & $20-24$ & 2.545 & $31.5 \%$ \\
\hline 3 & $25-29$ & 3.358 & $41.6 \%$ \\
\hline & Total & 8.072 & $100 \%$ \\
\hline
\end{tabular}

Sumber: Diolah dari data BPS, Kota Sabang dalam Angka 2017

Sampel penelitian ini adalah para pemuda dan pemudi yang berdomisili di Kota Sabang, Provinsi Aceh. Metode pengambilan sampel yang digunakan dalam penelitian ini dilakukan dengan sampel acak sederhana. Selanjutnya penentuan sampel dianggap representatif, yaitu dengan menggunakan rumus slovin dengan rincian:

$$
n=\frac{N}{1+N e^{2}}
$$

Dengan demikian jumlah sampel dalam penelitian ini adalah:

$$
n=\frac{8072}{1+8072\left(0.1^{2}\right)}
$$

Teknis dalam pengambilan sample menggunakan accidental sampling, yang dalam teorinya (Sugiyono, 2010) menentukan sampel berdasarkan kebetulan. Berdasarkan pernyataan yang telah peneliti paparkan sebelumya, sampel dalam penelitian ini yang semula berjumlah 99 orang, dibulatkan menjadi 100 orang sampel. Teknik pengambilan sampel dimana seluruh responden dalam penelitian ini menjadi sama (probability sampling), dengan 
cara (simple random sampling). Data primer yang diteliti menggunakan kuisioner dengan mengujinya menggunakan skala Likert.

Tabel 2. Jumlah Sampel

\begin{tabular}{|c|c|c|c|}
\hline No & KETERANGAN & n & PERSENTASE \\
\hline 1 & $15-19$ & 26.61 & $26.88 \%$ \\
\hline 2 & $20-24$ & 31.21 & $31.52 \%$ \\
\hline 3 & $25-29$ & 41.18 & $41.60 \%$ \\
\hline & Total & 99 & $100 \%$ \\
\hline
\end{tabular}

Sumber: Hasil Olahan Peneliti 2020

Analisis ini dipilih untuk memudahkan peneliti dalam melakukan penjajalan sejauh mana foktor-faktor sosial dari Umur $\left(\mathrm{X}_{1}\right)$, Jenis Kelamin (gender) $\left(\mathrm{X}_{2}\right)$, Pendidikan Formal $\left(\mathrm{X}_{3}\right)$, Pendidikan Informal $\left(\mathrm{X}_{4}\right)$ dan Pekerjaan $\left(\mathrm{X}_{5}\right)$ dapat berpengaruh terhadap peran pemuda dalam pengembangan wisata halal di Kota Sabang (Y). Metode analisis data yang digunakan adalah regresi linear berganda, dengan menganalisis faktor-faktor sosial yang berpengaruh terhadap peran pemuda dalam pengembangan wisata halal di Kota Sabang. Dalam artian variabel independen mempunyai pengaruh nyata atau tidak nyata terhadap variabel dependen. Model regresi dalam penelitian ini adalah sebagai berikut:

$$
\mathrm{Y}=a+\mathrm{b}_{1} \mathrm{X}_{1}+\mathrm{b}_{2} \mathrm{X}_{2}+\mathrm{b}_{3} \mathrm{X}_{3}+\mathrm{b}_{4} \mathrm{X}_{4}+\mathrm{b}_{5} \mathrm{X}_{5}+e
$$

Pengujian statistik dilakukan dengan menggunakan uji-F (F-test) dan uji-t (t-test) serta perhitungan nilai koefisien determinasi R2. Uji-F dimaksudkan untuk mengetahui signifikansi statistik koefisien regresi independen variabel terhadap dependen variabel secara simultan atau bersamaan. Sedangkan Uji-t dimaksud untuk mengetahui signifikansi statistik koefisien regresi independen variabel terhadap dependen variabel secara parsial atau sendirisendiri.

\section{HASIL DAN PEMBAHASAN}

Hasil dari persamaan regresi linier berganda bahwasannya foktor-faktor sosial dari $\left(\mathrm{X}_{1}\right),\left(\mathrm{X}_{2}\right),\left(\mathrm{X}_{4}\right)$ dan $\left(\mathrm{X}_{5}\right)$ dapat berpengaruh terhadap $(\mathrm{Y})$ secara positif. Peran pemuda yang memberikan pengaruh positif terhadap pengembangan wisata halal di Kota Sabang tersebut secara implisit sejalan dengan teori yang dikemukakan oleh (Ahmadi, 1997) memaparkan yang pertama pemuda sebagai (agent of change) berfungsi untuk perubahan berkenaan tentang kemanusiaan dengan membaktikan ilmu pengetahuan yang dimiliki terhadap masyarakat, sehingga kegiatan pengabdian yang dilangsungkan tampak terperogram dengan 
sistematis. Kedua Sebagai (agent of development) berperan secara fisik maupun non fisik yang berperan menjadi pembaharu pembangunan. Terakhir sebagai (agent of modernisation) tidak hanya dituntut untuk selalu inovatif, namun pemuda juga diharuskan untuk lebih cermat memilih sesuatu yang pantas diganti atau sebaliknya. Pengaruh positif yang dilakukan pemuda dalam pengembangan wisata halal di Kota Sabang juga sesuai yang terkandung pada Pasal 16 ayat 3 pada Undang-Undang Nomor 40 Tahun 2009 Tentang Kepemudaan.

Faktor-faktor sosial dari faktor umur berpengaruh positif dan signifikan terhadap peran pemuda. Pengaruh positif dan signifikan ini sesuai dengan Undang Undang Nomor 40 Tahun 2009 Tentang Kepemudaan yang terdapat pada Pasal 1 ayat 1. Peran pemuda dalam pengembangan wisata halal di Kota Sabang sangatlah penting dalam melanjutkan tongkat estapet yang ada dalam masyarakat, hal ini dikarenakan posisi pemuda sebagai penghubung antara generasi di atasnya dan generasi di bawahnya, dengan posisi seperti ini menjadikan pemuda sebagai rantai penghubung antar generasi. Hal ini sejalan dengan (Mikkelsen, 1999) bahwasannya tingkat keikutsertaan dilakukan secara sukarela dan mengerjakan sesuatu secara aktif dan inovatif dalam proses pembangunan.

Faktor jenis kelamin (gender) berpengaruh positif dan signifikan terhadap peran pemuda, hal ini mengindikasikan para pemuda memiliki hak dan tanggung jawab yang sama besarnya. Pemerintah Daerah Aceh juga menegaskan kesetaraan ini pada Qanun Aceh Nomor 6 Tahun 2009 Tentang Pemberdayaan dan Perlindungan Perempuan pada pasal 1 ayat 5 dan 6. Peran aktif yang merata antara pemuda ini secara implisif sejalan dengan pernyataan (Suryadi dan Idris, 2004) bahwasannya peran dalam strata sosial antara laki-laki dan perempuan merupakan tatanan budaya yang terjadi melalui kebiasaan, sosialisasi, adatistiadat, asimilasi dan akulturasi budaya yang berbeda disetiap wilayahnya.

Faktor-faktor sosial dari faktor pendidikan formal berpengaruh positif dan signifikan terhadap peran pemuda. Dari hasil tersebut membuktikan jika pendidikan pemuda memiliki pengaruh positif terhadap peran pemuda dalam pengembangan wisata halal di Kota Sabang. Hal ini sejalan dengan teori (Stuart dan Larala, 2009) yang mengatakan jenjang pendidikan seseorang tentunya berpengaruh terhadap kemampuan berpikir. Semakin tinggi jenjang pendidikan akan semakin mudah dalam menggunakan rasional serta menangkap informasi baru termasuk menguraikan masalah.

Faktor-faktor sosial dari faktor pendidikan informal berpengaruh positif tidak signifikan terhadap peran pemuda. Isu-isu berkembang terhadap pendidikan informal, bahwasannya selama ini telah terjadi pengkultusan secara yuridis terkait tidak dapat 
memberikan dampak terhadap peningkatan kepercayaan masyarakat dan akademis terhadap proses yang dihasilkan oleh pendidikan informal (Sudiapermana, 2013). Hal ini secara implisit sejalan dengan (Cahyadi, 2001) yang menyataan bahwasannya pendidikan keluarga meliputi pendidikan iman, pendidikan moral, pendidikan fisik, pendidikan intelektual, pendidikan psikis, pendidikan sosial dan pendidikan seksual.

Faktor-faktor sosial dari faktor pekerjaan berpengaruh positif tidak signifikan terhadap peran pemuda. Hasil ini mengingatkan kembali akan teori persepsi dalam psikologi bahwasannya persepsi senantiasa berhubungan dengan sensasi, sebab sensasi merupakan suksesi mencerna energi dari lingkungan sosial melalui indra (Chaplin, 2009). Dengan begini persepsi antar individu terhadap lingkungan sosial akan berlainan, sebab masing-masing individu akan merespons sesuai aspek yang dianggapnya memiliki kedudukan penting untuk dirinya (King, 2011). Secara implisit juga sejalan dengan yang diuraikan (Nuraini, 2013), bahwasannya pekerjaan bukan hanya semata tentang menghasilkan uang dan meningkatkan kesejahteraan saja, akan tetapi juga berkaitan dengan kehidupan sosial yang dapat meningkatkan derajat di tengah masyarakat.

Investasi Pemerintah Kota Sabang tidak hanya dari sumber daya alam saja, tetapi keseluruhan objek wisata yang terikut di dalamnya. Mulai dari para pengusaha penyedia fasilitas dan para pemuda sebagai pelayan wisatawan, selalu diikut sertakan dalam setiap rencana pembangunan dan pelatihan peningkatan kemampuan dalam pengelolaan industri pariwisata guna meningkatkan kunjungan wisatawan. Dengan adanya hal tersebut secara langsung dapat saling terkait dengan investasi lain dibidang penginapan, restoraran, jasa perjalanan dan boga. Keseluruhan investasi tersebut bertujuan untuk perluasan pembangunan dan pemerataan kesempatan kerja demi terwujudnya kesejahteraan masyarakat di Kota Sabang.

Keseluruhan pemuda di Kota Sabang telah menyadari bahwasannya ekonomi dan pariwisata saling mimiliki keterkaitan satu sama lain. Wisata halal memiliki peran penting terhadap masyarakat di Kota Sabang sebagai roda usaha yang tahan akan krisis, peningkatan roda ekonomi, tumbuhnya usaha lokal dan terciptanya lapangan kerja yang merata dan beragam.

Para pemuda juga memanfaatkan program yang telah digagas oleh pemerintah untuk mengikuti pelatihan berinai sebagai suatu kekhasan di Kota Sabang. Para pemuda bersama dinas terkait juga selalu gigih untuk tetap menjaga identitas mereka sebagai wilayah yang bersyariat dengan dimulai dari pemasangan baliho berisikan aturan-aturan syariat yang 
dipasang dengan tertata disepanjang pelabuhan Ule Lhee tujuan Kota Sabang dan pelabuhan Balohan di Kota Sabang, serta disepanjang kawasan-kawasan penginapan. Terkhusus ditempat penginapan dengan adanya para pemuda, tugas dari Wilayatul Hisbah (petugas syariat) agak sedikit berkurang. Dikarenakan para pemuda sangat perduli untuk menjaga Kota Sabang sebagai kota syariat dengan menejembatani antara Dinas Pariwisata dan Kebudayaan dan Dinas Syariat Islam Kota Sabang dengan mengadakan Forum Group Discussion (FGD) berkala untuk para pihak pengelola penginapan dan masyarakat secara umum.

Program kedepannya untuk pengembangan sumber daya manusia yang akan digagas para pemuda bekerjasama dengan Dinas terkait adalah menambah sumber daya manusia yang ahli dibidang Agama Islam sebagai bentuk pencegahan buta agama di Kota Sabang. Dengan tersedianya sumber daya yang ahli Agama Islam sebarang tentu sanggar kesenian yang diprogram Dinas Kebudayaan dan Pariwisata bisa mempertunjukkan budaya Islam saat perayaan hari besar nasional sebagai pertunjukan khas Kota Sabang. Program yang mengedepankan pemberdayaan ekonomi kerakyatan dari usaha kecil menengah juga dilakukan dengan melatih para pemuda dan masyarakat sekitar untuk memproduksi buah tangan atau oleh-oleh khas (something to buy) yang kesemuanya bertujuan untuk meningkatkan kenyawamanan dan daya tarik para wisatawan.

Pemerintah Kota Sabang dalam upaya pengembangan wisata halal akan menambah fasilitas ummat Islam yang semulanya di Kecamatan Sukajaya berjumlah 10 Masjid dan 29 Meunasah (bangunan khas Aceh yang difungsikan sebagai sentral budaya Islam) dan Kecamatan Sukakarya berjumlah 11 Masjid dan 31 Meunasah. Kedepannya akan dibangun Masjid-masjid yang dibangun memiliki ruang terbuka non hijau pada tingkat kelurahan, masing-masing gampong akan dibangun dengan luas lahan $3.600 \mathrm{~m}^{2}$ dan di tingkat kecamatan dibangun dengan luas lahan $5.400 \mathrm{~m}^{2}$. Bertambahnya fasilitas sarana dan prasarana (something to do) di Kota Sabang sebagai upaya pengembangan wisata halal yang bertujuan untuk meningkatkan kenyamanan para wisatawan.

Pengembangan wisata halal di Kota Sabang dalam penyediaan sarana prasarana seperti tempat penginapan, restoran dan produk-produk layanan meskipun tidak memiliki label halal bukan berarti apa yang telah disediakan jauh dari aturan yang telah ditetapkan, hal ini dikarenakan mayoritas masyarakat merupakan pemeluk agama Islam. Dalam prosedur home stay ataupun tempat penginapan lainnya pihak penyewa selalu memberikan syarat penyertaan Kartu Tanda Penduduk (KTP) sebagai pengganti buku nikah terhadap wisatawan yang berpasangan. Didalam tempat penginapan juga disediakan perlengkapan sholat beserta 
petunjuk arah kiblat. Meskipun fasilitas, sarana, produk dan layanan yang disediakan lebih condong diperuntukkan untuk wisatawan muslim, namun harus sama diketahui jika wisatawan non-muslim juga berhak untuk menikmati segala fasilitas, sarana, produk dan layanan yang telah disediakan.

\section{KESIMPULAN}

Faktor-faktor sosial pada indevenden variabel umur, jenis kelamin (gender), pendidikan formal, pendidikan informal dan pekerjaan secara simultan berpengaruh terhadap peran pemuda dalam pengembangan wisata halal di Kota Sabang.

Faktor-faktor sosial pada indevenden variabel umur, jenis kelamin (gender) dan pendidikan formal secara parsial berpengaruh signifikan sedangkan indevenden variabel pendidikan informal dan pekerjaan secara parsial tidak berpengaruh signifikan terhadap peran pemuda dalam pengembangan wisata halal di Kota Sabang.

\section{DAFTAR PUSTAKA}

Ahmadi, A. (1997). Strategi Belajar Mengajar. Pustaka Setia, Bandung.

Cahyadi, T. (2001). Pernak Pernik Rumah Tangga Islami, Era Intermedia, Solo.

Chaplin, J. P. (2009). Dictionary of Psychology. PT. Raja Grafindo Persada, Jakarta. Terjemahan dari: Kartini Kartono.

Fred. (2019). Retrieved from Federal Reserve Bank of St. Louis. Economic Research.

Gamal, S. (2004). Dasar-dasar Pariwisata. Andi, Yogyakarta.

Given, L. M. (2008). The Sage Encyclopedia of Qualitative Research Methods. Sage Publications, Inc Thousand Oaks, CA, California.

Jaelani, A. (2016). Islamic Tourism Development in Cirebon: The Study Heritage Tourism in Islamic Economic Perspective. Journal of Economics Bibliography, 3(2): 215-235.

Jafari, J., dan Scott N. (2014). Muslim World and its Tourisms. Annals of Tourism Research, 44: $1-19$.

King, L. A. (2011). Introduction to Psychology: The Science of Psychology: an Appreciative View. Learning Solutions, McGraw-Hill. Jakarta: 2017, Psikologi Umum: Sebuah Pandangan Apresiatif. Terjemahan dari: Yuditha Hardini.

Mikkelsen, B. (1999). Metode Penelitian Partisipatoris dan Upaya-upaya Pemberdayaan: sebuah Buku Pegangan bagi Para Praktisi Lapangan. Yayasan Obor Indonesia, Jakarta.

Nuraini, S.A. (2013). Makna Kerja (Meaning of Work) Suatu Studi Etnografi Abdi Dalem Keraton Ngayogyakarta Hadiningrat Daerah Istimewa Yogyakarta. Psikologi Industri dan Organisasi UNAIR, Surabaya 3: 157-162.

Setiawan, I. (2015). Potensi Destinasi Wisata di Indonesia Menuju Kemandirian Ekonomi. Prosiding SENDI-U, ISBN: 978-979-3649-81-8. 
Stuart G.W, Larala. M.T. (2009). Principles and Practice of Psychiatric Nursing $9^{\text {th }}$. Elsever. St. Louis: Mosby Year B.

Sudiapermana, E. (2013). Pendidikan Nonformal dan Informal. Edukasia Press, Bandung.

Sugiyono. (2010). Metode Penelitian Pendidikan Pendekatan Kuantitatif, kualitatif, dan R\&D. Alfabeta, Bandung.

Suryadi dan Idris, A.E. (2004). Kesetaraan Jender dalam Bidang Pendidikan. PT. Genesindo, Bandung.

Wilson, J.A.J, dan Liu, J. (2011). The challenges of Islamic branding: navigating emotions and halal. Journal of Islamic marketing, 2/1: 28-42.

Zalikha. (2015). Peluang dan Tantangan Pelaksanaan Wisata di Kota Sabang. Jurnal Albayan, 22/31: 90-137.

[BAPPENAS] Badan Perencanaan Pembangunan Nasional. (2018). Master Plan Ekonomi Syariah Indonesia 2019-2024 (Hasil Kajian Analisis Ekonomi Syariah di Indonesia. PT. Zahir Syariah Indonesia, Jakarta.

[BPS] Badan Pusat Statistik. (2008). Data Strategis BPS 2008. ISSN/ ISBN: 978-979-724903-4.

[BPS] Badan Pusat Statistik. (2014). Statistik Pemuda Indonesia 2014. Badan Pusat Statistik, Jakarta. ISSN: 2086-1028.

[DSN-MUI] Dewan Syariah Nasional Nomor. 2016. Tentang Pedoman Penyelenggaraan Wisata Berdasarkan Prinsip Syariah, Jakarta.

[PEMDA] Qanun Aceh. (2009). Tentang Pemberdayaan dan Perlindungan Perempuan. Qanun Aceh Nomor 6 Tahun 2009, Aceh.

[PEMDA] Qanun Aceh. (2013). Tentang Kepariwisataan. Qanun Aceh Nomor 8 Tahun 2013, Aceh.

[PEMDA] Qanun Aceh. (2016). Tentang Sistem Jaminan Produk Halal. Qanun Aceh Nomor 8 Tahun 2016, Aceh.

[PEMKO] Rencana Pembangunan Jangka Panjang Kota Banda Aceh. (2007). RPJP Kota Banda Aceh 2007-2027, Aceh.

[PERMENDIKBUD RI] Peraturan Menteri Pendidikan dan Kebudayaan Republik Indonesia. (2017). Tentang Pelibatan Keluarga Pada Penyelenggaraan Pendidikan. PERMENDIKBUD RI Nomor 30 Tahun 2017, Jakarta.

[PERWALI] Peraturan Walikota Banda Aceh. (2016). Tentang Penyelenggaraan Wisata Halal. PERWALI Kota Banda Aceh Nomor 17 Tahun 2016, Aceh.

[PP] Peraturan Pemerintah. (2011). Tentang Rencana Induk Pembangunan Kepariwisataan Nasional Tahun 2010-2025. LN. No. 125, TLN No. 5262, LL SETNEG, Jakarta.

[PPN/ BAPPENAS] Perencanaan Pembangunan Nasional/ Badan Perencanaan Pembangunan Nasional. (2017). Indeks Pembangunan Pemuda Indonesia 2017. PPN/ BAPPENAS 2017, Jakarta.

[UPM] Rezai, G. (2008). Consumers' Confidence in Halal Labeled Manufactured Food in Malaysia. Tesis. University Putra Malaysia, Malaysia. 


\section{LAMPIRAN}

Tabel 3. Pengujian Validitas dan Realibilitas Variabel Faktor-Faktor Sosial

\begin{tabular}{|c|c|c|c|c|c|c|}
\hline Variabel & $\begin{array}{c}\text { Butir } \\
\text { Pertanyaan }\end{array}$ & $\begin{array}{c}\text { r- } \\
\text { hitung }\end{array}$ & Sig & $\begin{array}{c}\text { r-tabel } \\
>0.361\end{array}$ & $\begin{array}{c}\text { Koefisien } \\
\text { Alpha }\end{array}$ & $\begin{array}{c}\text { r-tabel } \\
>0.6\end{array}$ \\
\hline \multirow{4}{*}{ Umur } & 1 & 0.875 & 0.000 & Valid & \multirow{4}{*}{0.752} & \multirow{4}{*}{ Reliabe } \\
\hline & 2 & 0.884 & 0.000 & Valid & & \\
\hline & 3 & 0.796 & 0.000 & Valid & & \\
\hline & 4 & 0.543 & 0.000 & Valid & & \\
\hline \multirow{4}{*}{$\begin{array}{l}\text { Jenis Kelamin } \\
\text { (gender) }\end{array}$} & 1 & 0.819 & 0.000 & Valid & \multirow{4}{*}{0.852} & \multirow{4}{*}{ Reliabel } \\
\hline & 2 & 0.834 & 0.000 & Valid & & \\
\hline & 3 & 0.887 & 0.000 & Valid & & \\
\hline & 4 & 0.818 & 0.000 & Valid & & \\
\hline \multirow{4}{*}{$\begin{array}{l}\text { Pendidikan } \\
\text { Formal }\end{array}$} & 1 & 0.739 & 0.000 & Valid & \multirow{4}{*}{0.708} & \multirow{4}{*}{ Reliabel } \\
\hline & 2 & 0.813 & 0.000 & Valid & & \\
\hline & 3 & 0.802 & 0.000 & Valid & & \\
\hline & 4 & 0.537 & 0.000 & Valid & & \\
\hline \multirow{4}{*}{$\begin{array}{l}\text { Pendidikan } \\
\text { Informal }\end{array}$} & 1 & 0.888 & 0.000 & Valid & \multirow{4}{*}{0.892} & \multirow{4}{*}{ Reliabel } \\
\hline & 2 & 0.816 & 0.000 & Valid & & \\
\hline & 3 & 0.909 & 0.000 & Valid & & \\
\hline & 4 & 0.871 & 0.000 & Valid & & \\
\hline \multirow{4}{*}{ Pekerjaan } & 1 & 0.791 & 0.000 & Valid & \multirow{4}{*}{0.646} & \multirow{4}{*}{ Reliabel } \\
\hline & 2 & 0.865 & 0.000 & Valid & & \\
\hline & 3 & 0.599 & 0.000 & Valid & & \\
\hline & 4 & 0.459 & 0.000 & Valid & & \\
\hline
\end{tabular}

Sumber: Hasil Penelitian 2020 (diolah dengan aplikasi SPSS 17)

Tabel 4. Pengujian Validitas dan Realibilitas Variabel Peran Pemuda

\begin{tabular}{|c|c|c|c|c|c|c|}
\hline Variabel & $\begin{array}{c}\text { Butir } \\
\text { Pertanyaan }\end{array}$ & $\begin{array}{c}\mathrm{r}- \\
\text { hitung }\end{array}$ & Sig & $\begin{array}{c}\text { r-tabel } \\
>0.361\end{array}$ & $\begin{array}{c}\text { Koefisien } \\
\text { Alpha }\end{array}$ & $\begin{array}{c}\text { r-tabel } \\
>0.6\end{array}$ \\
\hline \multirow{13}{*}{$\begin{array}{l}\text { Peran Pemuda } \\
\text { dalam } \\
\text { Pengembangan } \\
\text { Wisata Halal }\end{array}$} & 1 & 0.856 & 0.000 & Valid & \multirow{13}{*}{0.922} & \multirow{13}{*}{ Reliabel } \\
\hline & 2 & 0.817 & 0.000 & Valid & & \\
\hline & 3 & 0.384 & 0.000 & Valid & & \\
\hline & 4 & 0.899 & 0.000 & Valid & & \\
\hline & 5 & 0.850 & 0.000 & Valid & & \\
\hline & 6 & 0.746 & 0.000 & Valid & & \\
\hline & 7 & 0.887 & 0.000 & Valid & & \\
\hline & 8 & 0.517 & 0.000 & Valid & & \\
\hline & 9 & 0.874 & 0.000 & Valid & & \\
\hline & 10 & 0.416 & 0.000 & Valid & & \\
\hline & 11 & 0.539 & 0.000 & Valid & & \\
\hline & 12 & 0.826 & 0.000 & Valid & & \\
\hline & 13 & 0.862 & 0.000 & Valid & & \\
\hline
\end{tabular}




\begin{tabular}{cccc}
\hline 14 & 0.881 & 0.000 & Valid \\
\hline 15 & 0.846 & 0.000 & Valid \\
\hline 16 & 0.472 & 0.000 & Valid \\
\hline 17 & 0.517 & 0.000 & Valid \\
\hline 19 & 0.461 & 0.000 & Valid \\
\hline 20 & 0.365 & 0.000 & Valid \\
\hline
\end{tabular}

Sumber: Hasil Penelitian 2020 (diolah dengan aplikasi SPSS 17)

Tabel 5. Analisis Regresi Linier Berganda

\begin{tabular}{|c|c|c|c|c|}
\hline \multicolumn{5}{|c|}{ Coefficients $^{\mathrm{a}}$} \\
\hline & \multirow{2}{*}{$\begin{array}{c}\text { Model } \\
\text { (Independen Variabel) }\end{array}$} & \multicolumn{2}{|c|}{$\begin{array}{c}\text { Unstandardized } \\
\text { Coefficients }\end{array}$} & \multirow{2}{*}{$\begin{array}{c}\begin{array}{c}\text { Standardized } \\
\text { Coefficients }\end{array} \\
\text { Beta }\end{array}$} \\
\hline & & B & Std. Error & \\
\hline \multirow{6}{*}{1} & (Constant) & 5.660 & 10.048 & .309 \\
\hline & Umur X1 & 1.309 & .355 & .446 \\
\hline & Jenis Kelamin (Gender) X2 & 2.578 & .474 & .178 \\
\hline & Pendidikan Formal X3 & .484 & .212 & .002 \\
\hline & Pendidikan Informal X4 & .006 & .256 & .078 \\
\hline & Pekerjaan X5 & .228 & .227 & \\
\hline
\end{tabular}

a. Dependent Variable: Peran Pemuda dalam Pegembangan Wisata Halal Y

Sumber: Diolah dengan aplikasi SPSS 17

Hasil dari persamaan regresi linier berganda sebagai berikut:

$\mathrm{Y}=5.660+1.309 \mathrm{X}_{1}+2.578 \mathrm{X}_{2}+0.484 \mathrm{X}_{3}+0.006 \mathrm{X}_{4}+0.228 \mathrm{X}_{5}+\mathrm{e}$

Tabel 6. Hasil Uji Koefisien Determinasi $\left(\mathrm{R}^{2}\right)$

\begin{tabular}{ccccc}
\hline \multicolumn{4}{c}{ Model Summary } \\
\hline Model & $\mathrm{R}$ & R Square & $\begin{array}{c}\text { Adjusted R } \\
\text { Square }\end{array}$ & Std. Error of the Estimate \\
\hline 1 & $.692^{\mathrm{a}}$ & .479 & .451 & 6.806 \\
\hline
\end{tabular}

a. Predictors: (Constant), Pekerjaan X5, Pendidikan Informal X4, Pendidikan Formal X3, Jenis Kelamin (Gender) X2, Umur X1

Sumber: Diolah dengan aplikasi SPSS 17

Tabel 7. Hasil Uji Simultan atau Bersamaan (Uji F)

\begin{tabular}{llcrrrrr}
\hline \multicolumn{7}{c}{ ANOVA $^{\mathrm{b}}$} \\
\hline \multirow{3}{*}{ Model } & \multicolumn{1}{c}{ Sum of } & & & & & \\
\hline \multirow{2}{*}{1} & Squares & df & Mean Square & F & Sig. \\
\cline { 2 - 8 } & Regression & 3999.392 & 5 & 799.878 & 17.269 & $.000^{\mathrm{a}}$ \\
\cline { 2 - 8 } & Residual & 4353.998 & 94 & 46.319 & & \\
\hline
\end{tabular}




Total $8353.390 \quad 99$

a. Predictors: (Constant), Pekerjaan X5, Pendidikan Informal X4, Pendidikan Formal X3, Jenis Kelamin (Gender) X2, Umur X1

b. Dependent Variable: Peran Pemuda dalam Pegembangan Wisata Halal Y

Sumber: Diolah dengan aplikasi SPSS 17

Tabel 8. Hasil Uji Parsial atau Sendiri-sendiri (Uji t)

\begin{tabular}{llcc}
\hline \multicolumn{3}{c}{ Coefficients $^{\mathbf{a}}$} \\
\hline \multirow{2}{*}{1} & \multicolumn{1}{c}{ Model } & $\mathrm{t}$ & \multicolumn{1}{c}{ Sig. } \\
\hline \multirow{3}{*}{1} & (Constant) & .563 & .575 \\
\cline { 2 - 4 } & Umur X1 & 3.689 & .000 \\
\cline { 2 - 4 } & Jenis Kelamin (Gender) X2 & 5.444 & .000 \\
\cline { 2 - 4 } & Pendidikan Formal X3 & 2.284 & .025 \\
\cline { 2 - 4 } & Pendidikan Informal X4 & .024 & .981 \\
\cline { 2 - 4 } & Pekerjaan X5 & 1.004 & .318 \\
\hline
\end{tabular}

a. Dependent Variable: Peran Pemuda dalam Pegembangan Wisata Halal Y

Sumber: Diolah dengan aplikasi SPSS 17 